OPEN ACCESS

Edited by:

Eric Cox,

Ghent University, Belgium

Reviewed by:

Yang Qiu,

Chinese Academy of Sciences, China

Muneeb A. Faiq,

New York University, United States

${ }^{*}$ Correspondence:

Zhenqiang Sun

fccsunzq@zzu.edu.cn

${ }^{\dagger}$ These authors have contributed equally to this work

Specialty section: This article was submitted to Mucosal Immunity,

a section of the journal

Frontiers in Immunology

Received: 01 March 2021 Accepted: 18 October 2021 Published: 10 November 2021

Citation:

Zhang $H$, Shao B, Dang Q, Chen Z, Zhou Q, Luo H, Yuan W and Sun Z (2021) Pathogenesis and

Mechanism of Gastrointestinal Infection With COVID-19.

Front. Immunol. 12:674074. doi: 10.3389/fimmu.2021.674074

\section{Pathogenesis and Mechanism of Gastrointestinal Infection With COVID-19}

\author{
Hao Zhang ${ }^{1+}$, Bo Shao ${ }^{1 \dagger}$, Qin Dang ${ }^{1}$, Zhuang Chen ${ }^{1}$, Quanbo Zhou ${ }^{1}$, Hong Luo ${ }^{3}$, \\ Weitang Yuan ${ }^{1}$ and Zhenqiang Sun ${ }^{1,2 *}$ \\ ${ }^{1}$ Department of Colorectal Surgery, The First Affiliated Hospital of Zhengzhou University, Zhengzhou, China, ${ }^{2}$ Academy of \\ Medical Sciences, Zhengzhou University, Zhengzhou, China, ${ }^{3}$ Department of Hepatobiliary and Pancreatic Surgery, \\ Guangshan County People's Hospital, Xinyang, China
}

As a new infectious disease, COVID-19 is spread through the respiratory tract in most cases. Its source and pathological mechanism are not clear. The most common clinical feature is pulmonary infection. Also, a lot patients have gastrointestinal symptoms. Angiotensin-converting enzyme 2 (ACE2) is a functional cellular receptor for SARSCoV-2, which is like SARS-CoV, a coronavirus associated with severe acute respiratory syndrome (SARS) outbreak in 2003. The tissues and cells expressing ACE2 are potential targets for SARS-CoV-2 infection, and the high expression of ACE2 in intestinal epithelial cells marks that SARS-CoV-2 may directly infect intestinal epithelial cells. Recent studies also suggest that SARS-CoV-2 existed and replicated in intestinal environment for a long time. The interaction between SARS-CoV-2 and RAS system leads to the decrease of local anti-inflammatory ability. The virus cycle leads to excessive imbalance of immune response and cytokine release. The downregulation of ACE2 after viral infection leads to gastrointestinal dysfunction. The above are the causes of gastrointestinal symptoms. Here, we reviewed the possible causes and mechanisms of gastrointestinal symptoms caused by COVID-19. Additionally, we discussed the influence of gastrointestinal symptoms on the prognosis of patients.

Keywords: angiotensin-converting enzyme 2 (ACE2), gastrointestinal tract, gut-lung axis, cytokine storm, coronavirus disease 2019 (COVID-19), RAS system

\section{INTRODUCTION}

Since the end of 2019, COVID-19 has begun to spread rapidly around the world (1). Recent studies showed the persistent positive rate of SARS-CoV-2 in stool specimens of patients with COVID-19 (2). After a negative respiratory test, the continuous detection of SARS-CoV-2 in stool specimens or anal swabs takes a long time. The duration of virus positive in stool specimens may be longer than that in respiratory specimens $(3,4)$. Not only that, the results of Lin et al.'s research also showed that 
some patients (27.3\%) did not have any lung imaging features of COVID-19, but had gastrointestinal symptoms, indicating that gastrointestinal tissues are susceptible to SARS-CoV-2 (5). It is very necessary for gastroenterologists to understand and explore the prevalence, pathogenesis, and clinical characteristics of SARS-CoV-2 infection in the gastrointestinal tract. Based on the current research between SARS-CoV-2 and the gastrointestinal mucosa, this article speculates about how SARS-CoV-2 causes gastrointestinal symptoms. Finally, we briefly summarize the gastrointestinal symptoms of COVID-19 patients and their impact on the prognosis of the disease.

\section{HOW SARS-CoV-2 INFECTS HUMAN TISSUE CELLS}

Current research shows that angiotensin-converting enzyme 2 (ACE2) is the receptor for SARS-CoV-2 $(6,7)$. ACE2 is expressed in human lung and intestinal epithelial cells $(7,8)$, and its expression in the intestine is more than four times that of other tissues (9). Also, ACE2 is highly expressed in proximal and distal small intestine cells (10). Through the detection of stool samples of confirmed cases, it was found that the detection rate of SARS-CoV-2 nucleic acid in stool samples was the same as the detection rate of throat swab samples (11).In the study of Xiao et al., infectious SARS-CoV-2 was isolated from stool, and positive staining of ACE2 and SARS-CoV-2 was observed in patients with positive stool test (12). Research shows that SARS$\mathrm{CoV}-2$ viruses can survive at a wide range of $\mathrm{pH}$ values at room temperature. The highly viscous mucus in the gastrointestinal tract protects viral RNA and virus particles, allowing the virus to retain its infectivity. Then, the virus is excreted with the feces (13, 14). Inflammatory conditions in the gastrointestinal tract disrupt the multi-layer barrier system and increase the expression of ACE2 in the intestinal epithelium. This allows SARS-CoV-2 to enter the intestinal epithelial cells (15). These can provide support for the hypothesis of fecal-oral transmission of SARS$\mathrm{CoV}-2$. Other than the fecal-oral route, an alternative route of viral entry to the GI cells may be through the tissue microvasculature. This will be further elaborated below.

However, whether SARS-CoV-2 can be transmitted through the fecal-oral route is still controversial. Infectious virus was isolated from intestinal tissue but not fecal specimens (16). Jeong et al. failed to directly prove the presence of viable SARSCoV-2 in stool samples by cell culture isolation (17). Detection of high copy numbers of viral RNA in the stool does not equate to shedding of infectious viruses or transmission of the disease (18). Respiratory transmission was not specifically blocked, making it difficult to attribute the transmission to the fecaloral route. Is the fecal viral load sufficiently high for human transmission? How long can the excreted virus persist in the environment? Can fecally shed virus infect animals that may serve as a reservoir for spread? During transmission, can gut be the first site of infection or does the virus spread to the gut from the respiratory or other tissues (18)? These all require more specific experimental demonstrations.

\section{THE MECHANISM OF SARS-CoV-2 CAUSING GASTROINTESTINAL SYMPTOMS}

\section{The Characteristics of SARS-CoV-2 Infection of Intestinal Cells and the Interaction With ACE2}

SARS-CoV-2 infection of intestinal cells mainly has the following two characteristics. First, the immune response induced by SARS-CoV-2 is different. Under in vitro conditions, SARSCoV-2 was observed to infect human intestinal epithelial cells and mesenteric cells, leading to their apoptosis (19). The replication efficiency of SARS-CoV-2 is lower than that of SARS-CoV. The cytopathology induced in human intestinal epithelium is relatively less, and it induces a stronger innate immune response, including more powerful interferon and proinflammatory response (20). Second, lung infections can be accompanied by gastrointestinal infections, which can lead to recurrence of the disease. For patients who experienced recurrence, the phylogenetic analysis of the full-length SARS$\mathrm{CoV}-2$ genome in the gastrointestinal tract showed that the virus detected in the positive retest evolved from the original parent virus (21). Some patients still have a positive stool test when the throat swab test is concealed (22-24).This suggests that SARSCoV-2 exists and replicates at a low level in the intestine for a long time (21). This is because in the early stage of new coronavirus infection, it is difficult for a small number of patients to quickly obtain immunity to SARS-CoV-2 and produce targeted IgM or IgG, which eventually causes the virus to persist in the gastrointestinal tract for a long time $(25,26)$. A recent study pointed out that the virus can hide in the mesenteric tissue and infect the lungs through the vasculature, causing disease (27).

We know that the renal angiotensin system (RAS) regulates systemic or local body functions and plays an important role in regulating blood pressure, electrolytes, organ functions, etc. (28). RAS is regulated by the opposing actions of two key carboxypeptidases, angiotensin-converting enzyme (ACE) and ACE2 $(29,30)$. Angiotensin II (AngII) is a vasoactive substance that can raise blood pressure. AngII is a vasoconstrictor, its overproduction causes inflammation $(31,32)$, and ACE2 is an enzyme that converts AngII, the main biologically active molecule of RAS, into Ang 1-7 $(33,34)$. The physiological significance is to exert anti-inflammatory and anti-remodeling effects (35). Recent reports showed that the S protein of COVID-19 would use the same receptor ACE2 as SARS-CoV to infect the host (36-39). Furthermore, the expression of ACE2 protein was downregulated after the virus infects the host (7). The lack of ACE2 was due to the internalization of the SARS-CoV-2-ACE2 complex, which limited the role of ACE2 as the carboxypeptidase of AngII and desarginine-bradykinin and other polypeptide hormones $(40,41)$. Based on this, we speculate that COVID-19 will cause the downregulation of ACE2 in the intestinal mucosal cells during the infection process, leading to the disorder of the RAS system and the decline of the anti-inflammatory ability of the intestinal mucosa (Figure 1). This is one of the reasons why people infected with the new coronavirus have intestinal symptoms. 


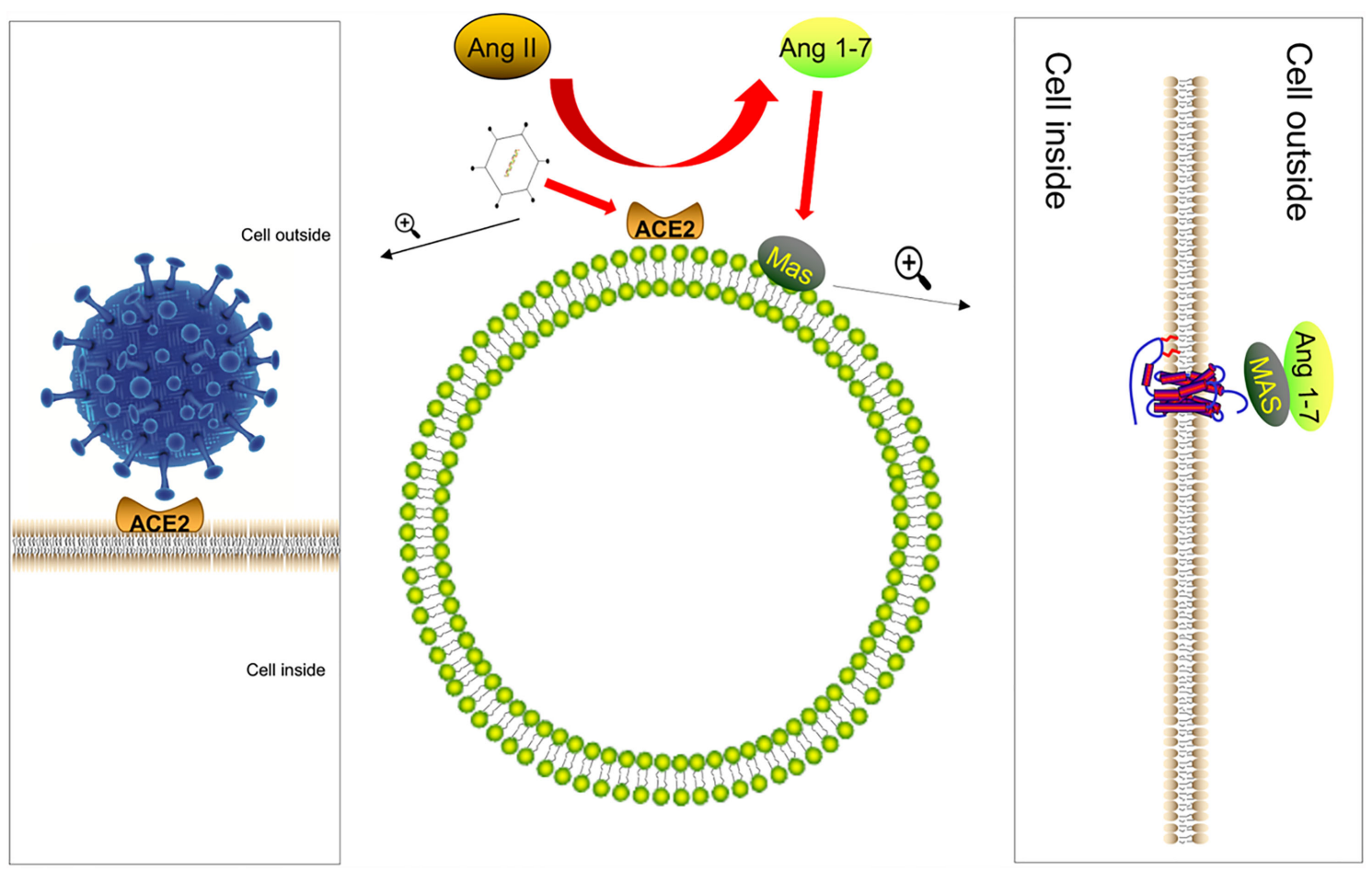

FIGURE 1 | The S protein of COVID-19 infects the host by combining with ACE2. After the virus infects the host, the expression of ACE2 protein is downregulated. ACE2 converts Ang II, the main biologically active molecule of RAS, to Ang 1-7; Ang (1Mel7) has anti-inflammatory and anti-remodeling effects after binding to the Mas receptor and coupling with Gq protein. Therefore, after the virus infects the host, it is likely to cause the intestinal anti-inflammatory ability to decrease.

There are very few reports about SARS-CoV-2 infection leading to viremia $(42,43)$. Recently, in a case, researchers isolated and cultured a live SARS-CoV-2 virus strain from the stool of an advanced patient and believed that SARS-CoV-2 might be able to migrate from the lungs to the blood circulation to the digestive tract (44). We agree with this view, but when viremia is present, patients often have severe systemic inflammation and cytokine storms (45). We believe viremia may be a stage that causes intestinal symptoms in patients, but it is not the main cause of intestinal damage.

\section{Immediate Immune Response and Inflammatory Factor Storm Caused by SARS-CoV-2 Infection and Intestinal Tissue Damage}

In the early stage of SARS-CoV-2 infection, the body's immediate immune response to the virus can effectively clear up the virus (46). Stimulation of innate immune cells leads to secretion of inflammatory mediators, which together with complement system exert antiviral effects in the early stage (47). Viruses evolved to have various strategies to circumvent the innate immune response. For example, viruses can evade the complement system by removing antibody-antigen complexes from cell surfaces, decreasing Fc receptor expression, or by mimicking the complement regulatory component $(48,49)$. Studies have shown that the replication efficiency of SARS-
$\mathrm{CoV}-2$ is lower, and the natural immune response (including the activation of type I and type III interferons) induced in human intestinal tissue is stronger than SARS-CoV (20). Due to the complex virus-innate immune interaction, the immune system may sometimes delay recovery, eventually leading to the patient's disease progression and even death (46).

In colonic epithelial cells expressing ACE2 positively, viral infection was significantly enhanced (50). After endocytosis, the positive-sense RNA highjacked cellular machinery for viral RNA and viral-specific protein synthesis. Viral particles were then assembled in the cellular cytoplasm and released into the gastrointestinal (GI) tract (51). In the lungs, due to the presence of ACE2 receptors, blood vessels in the lungs can easily become targets, triggering microthrombosis, immune complex deposition, and excessive humoral immune responses, leading to subsequent hypoxic damage to various important organs (52). From this, we speculate that the virus spreads through fecal-oral transmission to reach the gastrointestinal tract. In the intestine, virus particles reach ACE2-positive intestinal epithelial cells under the protection of the mucus layer (15). Infection of intestinal epithelial cells leads to the release of virus particles. The virus particles then reach the rich vascular network in the submucosa, eventually leading to local inflammation of the intestinal tract and secondary intestinal damage. In in vitro experiments, SARS-CoV-2 can infect and replicate effectively in isolated human intestinal tissues by 
releasing infectious virus particles, and the innate immune response induced in human intestinal tissues is stronger than SARS-CoV (53). Here, we will discuss the inflammatory response mechanism caused by SARS-CoV-2 infection that may lead to intestinal cell damage.

Increased levels of cytokines often occur in critically ill patients with COVID-19, including IL-6, IL-2R, IL-10, and tumor necrosis factor- $\alpha$ (54). An autopsy report showed that in patients with fatal new coronary pneumonia, there was a widespread systemic inflammation involving the gastrointestinal tract, and neutrophils and reticular structures persist. However, SARSCoV-2 infected cells were only occasionally seen in the late stage of new coronary pneumonia. This suggested a maladaptive immune response (55). In this maladaptive immune response, the direct cytopathological effects of SARS-CoV-2 induced apoptosis (a highly inflammatory form of programmed cell death) and release endogenous danger signals (56), which were local and remote recognition by epithelial cells, macrophages, and endothelial cells. A cascade of local inflammation ensued, characterized by secretion of pro-inflammatory cytokines and chemokines that attracted monocytes, macrophages, and $\mathrm{T}$ cells that mediated extensive pathology, culminating in tissue damage (57). When local inflammation occurs, macrophages frequently communicate with SARS-CoV-2 targets through chemokines and phagocytic signals (58), and inflammation may upregulate ACE2 expression on macrophages (59), further amplifying viral sensing and tissue injury (57). Postmortem analyses of secondary lymph nodes and spleen implicated CD169+ macrophages that contain viral nucleocapsid protein as mediators of activation-induced cell death (AICD) of lymphocytes (60). A recent study pointed out that SARS-CoV-2 induces IL-1 production in macrophages and mast cells (MCs), thereby inducing gene expression and activating other pro-inflammatory cytokines. Since IL-1 is toxic, IL-1 produced by ubiquitous MCs and macrophages activated by SARS-CoV-2 also causes gastrointestinal diseases. In addition, IL-1 also promotes the release of nitric oxide and the release of inflammatory arachidonic acid products such as prostaglandin and thromboxane A2 (61). All these effects will promote the generation and development of cytokine storms and lead to secondary intestinal damage.

In addition, patients with severe new-onset coronary pneumonia have significantly higher levels of IL-6 than patients with mild pneumonia (50). This may be because certain viral products (such as human immunodeficiency virus TAT protein transactivator) enhanced the DNA binding activity of nuclear factor $\kappa B(N F-\kappa B)$ and nuclear factor IL-6 (NF-IL-6), thereby increasing IL-6 mRNA transcription $(62,63)$. IL-6 is usually synthesized locally in the acute phase of inflammation and mediates the multidirectional effects of immune response and hematopoiesis (63). This cytokine also promotes the specific differentiation of normal CD4+ T cells, which is necessary for T-helper 17 (Th17) to differentiate from simple CD4+ T cells, and is related to immune tolerance, autoimmunity and chronic inflammatory diseases (64). The other reason is a potential dysregulation of the AngII-AT1R pathway downstream of ACE2. AngII not only acted as a vasoconstrictor, but also acted as a pro-inflammatory cytokine through AT1R (65). SARS-CoV-2 activated NF- $\kappa B$ and STAT3 through the AngI-AT1R pathway after SARS-CoV-2 infection, and then activated IL-6 amplifier (IL-6 Amp), which was a mechanism for STAT3 to overactivate $\mathrm{NF}-\kappa \mathrm{B}$ and led to various inflammations and autoimmune diseases (66). A meta-analysis showed that the inflammatory cytokines including IL-6, IL-10, and TNF- $\alpha$ were intensively increased in patients with diarrhea (67). Therefore, there is excessive activation of IL-1, IL-6, and NF- $\mathrm{KB}$ in the intestinal system, leading to various damages to the gastrointestinal tract.

\section{ACE2-Mediated Gastrointestinal Microbiota Imbalance and Intestinal Epithelial Injury}

Previous studies showed that the incidence of gastrointestinal symptoms in patients with COVID-19 was approximately $61 \%$. Symptoms such as diarrhea, vomiting, and abdominal pain were reported (5). If the presence of SARS-CoV-2 is detected in the gastrointestinal tract tissue, this usually means that the symptoms are severe. Another study also showed that the incidence of abdominal pain in patients entering the intensive care unit was significantly higher than that in patients who did not need to enter the intensive care unit (68). SARS-CoV in 2003 used the human ACE2 receptor to infect the host, and a considerable number of patients developed gastrointestinal symptoms (69). Recent studies reported that SARS-CoV-2 used ACE2 receptors more effectively than SARS-CoV (70). Therefore, we cannot ignore the effect of SARS-CoV-2 on ACE2 in the gastrointestinal tract.

ACE2 regulates the expression of the intestinal neutral amino acid transporter, which is very important for the composition of intestinal microbiota (71). Therefore, diarrhea and other gastrointestinal symptoms in patients with COVID-19 are likely to be related to the downregulation of ACE2 expression. Here, we summarize the possible causes and mechanisms of the effects of COVID-19 on the gastrointestinal tract. Studies showed that the transepithelial absorption of amino acids through intestinal epithelial cells referred to the sequential transport process through the lumen, brush border, and basolateral membrane, and the step of amino acids passing through the lumen required the mediation of various amino acid transporters.

Studies reported that sodium-dependent neutral amino acid transporter B(0)AT1 was expressed in small intestinal cells and plays an important role in amino acid absorption, while the expression and function of $\mathrm{B}(0) \mathrm{AT} 1$ depend on the existence of ACE2 (72). Hartnup disease is a rare autosomal recessive disease caused by $\mathrm{B}(0)$ AT1 gene mutation $(73,74)$. The disease causes obvious symptoms of diarrhea. Tatsuo et al. found that there was no change in the morphology and ultrastructure of the small intestine and large intestine in ACE2 knockout mice. However, after stimulation with sodium dextran sulfate (SDS), the intestines of ACE2 knockout mice showed more obvious inflammation, weight loss, and severe diarrhea (71). B(0)AT1 cannot be expressed in the intestines of ACE2 knockout mice, but dietary tryptophan is mainly absorbed through the B(0)AT1/ ACE2 transport pathway on the surface of the intestinal epithelium. As a result, the level of plasma tryptophan decreased significantly, while the deficiency of tryptophan and 
its metabolite nicotinamide decreased the activity of the mTOR pathway $(71,75)$. The mTOR pathway regulates the expression of antimicrobial peptides that affect intestinal microbiota. Changes in antimicrobial peptides will affect the ecology of large and small intestinal microbiota and cause local enteritis and diarrhea (71). Combined with a recent autopsy report of COVID-19 patients, intestinal injury was not obvious to the naked eye, and the small intestine showed phased dilatation and stenosis. Intestinal injury was probably caused by intestinal inflammation. The Susanna Nikolaus team studied 500 patients with inflammatory bowel disease and found that tryptophan deficiency promotes the development of inflammatory bowel disease and exacerbates disease activity (76). Therefore, we infer that the gastrointestinal symptoms in some patients with COVID-19 may be due to the downregulation of ACE2 expression, which affects the disturbance of tryptophan absorption and local enteritis caused by the ecology of intestinal microbiota through the above pathway (Figure 2). B (0)AT1 was also shown to interact with another coronavirus receptor, aminopeptidase $\mathrm{N}$ (APN) (77). All these findings suggest that $\mathrm{B}(0) \mathrm{AT} 1$ may have a certain regulatory effect on the ability of some coronaviruses to infect the intestine.

A recent study pointed out that several biosynthetic pathways, including the tryptophan biosynthetic pathway, will change in COVID-19 patients. This may be mainly caused by intestinal microbes. The study also found the depletion of several lowwater-soluble long-chain fatty acids or fatty alcohols, such as arachidic acid, behenic acid, and 1-hexadecanol, in the feces of COVID-19 patients (78). The abovementioned microorganismderived metabolites are closely related to regulating the host's inflammatory response and promoting tolerance and drug resistance to viral pathogens $(79,80)$. Understanding how SARS-CoV-2 causes changes in the intestinal microbiota and fecal metabolites is of great significance to the study of the mechanism of SARS-CoV-2 causing gastrointestinal symptoms.

\section{Thrombosis and Coagulopathy, Sepsis, and Gastrointestinal Injury}

Some recent cases reported repeated diarrhea, gastrointestinal bleeding, and acute mesenteric thrombosis in patients infected with the new coronavirus $(81,82)$. According to a recent study, bowel abnormalities were a common finding (31\%) during abdominal imaging of patients with COVID-19, and patients who required laparotomy often had histological ischemia due to small blood vessel thrombosis (83). An imaging study showed that in patients without COVID-19, the left flexure colon and sigmoid colon were at the highest risk of ischemic colitis, while the distal rectal segment usually survived due to its double blood supply, and in patients with COVID-19, seven cases have reported thickening of the colon/rectum. This difference in the

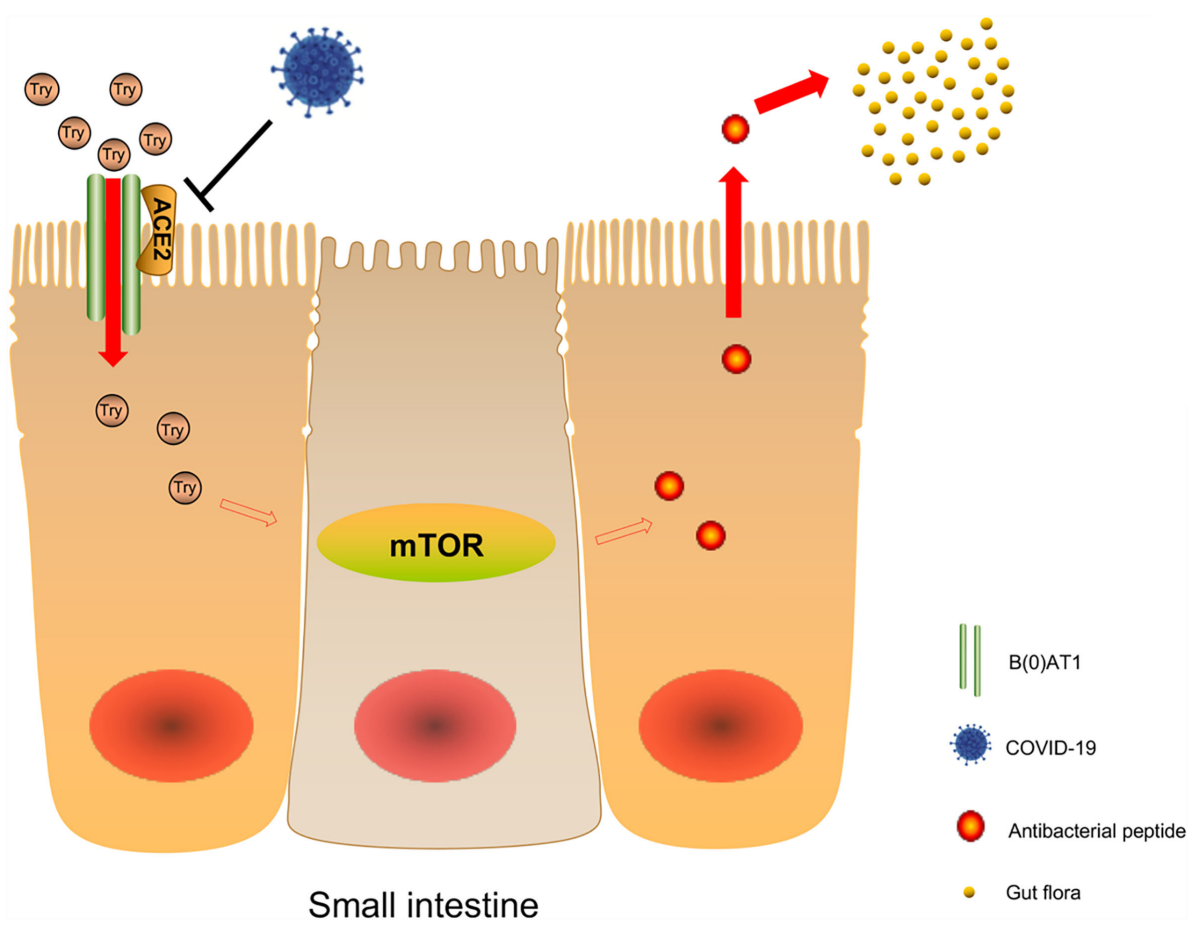

FIGURE 2 | Possible mechanism of COVID-19 affecting intestinal microbiota. Sodium-dependent neutral amino acid transporter B(0)AT1 is expressed in small intestinal cells and plays an important role in amino acid absorption, while the expression and function of B(O)AT1 depend on the existence of ACE2. After viral infection, the decrease of ACE2 expression will lead to the decrease of B(0)AT1 expression, and dietary tryptophan is mainly absorbed through the B0AT1/ACE2 transport pathway on the surface of the small intestine epithelium, resulting in a significant decrease in plasma tryptophan levels, and lack of tryptophan and its metabolite nicotinamide leads to a decrease in mTOR pathway activity, which affects the expression of antibacterial peptides in the intestinal flora. 
location of the disease also reveals the relationship between intestinal ischemic injury and SARS-CoV-2 infection $(83,84)$. A case report also confirmed that the gastrointestinal bleeding of patients with COVID-19 was caused by SARS-CoV-2 infection (85), and it was considered to be a thrombotic dysfunction caused by excessive inflammation, hypoperfusion, and even direct inflammation (86). Recent studies also reported patients who died of thrombotic diseases, or were infected with the new coronavirus with venous thromboembolism (VTE) and peripheral arterial thrombosis $(60,87,88)$. Here, we summarize the relevant mechanisms of intestinal coagulation diseases caused by SARS-CoV-2.

ACE2 and TMPRSS2 (a serine protease) are expressed in endothelial cells $(89,90)$, and the $S$ protein of the virus can also induce the downregulation of ACE2 (7). The downregulation of ACE2 is related to the local increase of Ang II (7). The increase of Ang- has a pro-inflammatory effect, leading to increased blood tumor necrosis factor- $\alpha$ and interleukin-6 levels (91). Both cytokines promote the rupture of the endothelial barrier (92) and reduce the level of Ang-(1-7) (93), leading to the occurrence of sepsis (94). Sepsis increases the level of inflammatory factors in the blood. Many cytokines are related to the production of blood's procoagulant state. For example, the increase of IL-6 level is related to the increase of fibrinogen level (95). Increased levels of cytokines also led to tissue damage, thrombotic microangiopathy, endotheliitis, and endothelial dysfunction (96). The direct attack of SARS-CoV-2 on the vascular endothelium eventually led to a vicious cycle between sepsis and increased cytokine levels. The damage of vascular endothelial cells and the increase of cytokines in the blood together led to the hypercoagulable state of the blood, which induced the occurrence of intestinal coagulation diseases.

In addition, studies showed that SARS-CoV-2 connected through the ACE2 receptor and enters cells, causing local inflammation and activating endothelial cells (97). The activation of lung endothelial cells led to the shedding of ACE1, which was described as the massive release of ACE1 from the cell membrane, followed by a rapid increase in the level of AngII, leading to inflammation, coagulation and capillary leakage (98). Here, we make an assumption: ACE1 shedding may also occur in infected intestinal endothelial cells. When the free ACE1 in the blood disappears, AngII will also drop to a very low level. Decreased levels of AngII can induce ACE2 synthesis, and may cause more SARS-CoV-2 to enter tissue cells (99) (Figure 3).

The increased levels of D-dimer and fibrinogen in many patients with COVID-19 may not only be a common cause of peripheral and pulmonary thrombosis, but also be the main cause of intestinal hypercoagulability and ischemic events (100, 101). Among patients hospitalized with COVID-19, the proportion of patients with D-Dimer increased as high as $47 \%$ (102). Compared with patients with coagulopathy, the most typical manifestation of patients with COVID-19 was increased D-dimer concentration (101). IL-6 induced mononuclear cells to express tissue factor, which in turn caused coagulation activation and thrombin generation. TNF- $\alpha$ and IL- 1 are the main mediators that inhibit the endogenous anticoagulation pathway (103). Therefore, it is necessary to detect the levels of D-dimer and IL-6, TNF- $\alpha$, and IL- 1 to prevent and predict the intestinal coagulation disease of COVID-19. Polyphosphates are derived from microorganisms; activate platelets, mast cells,

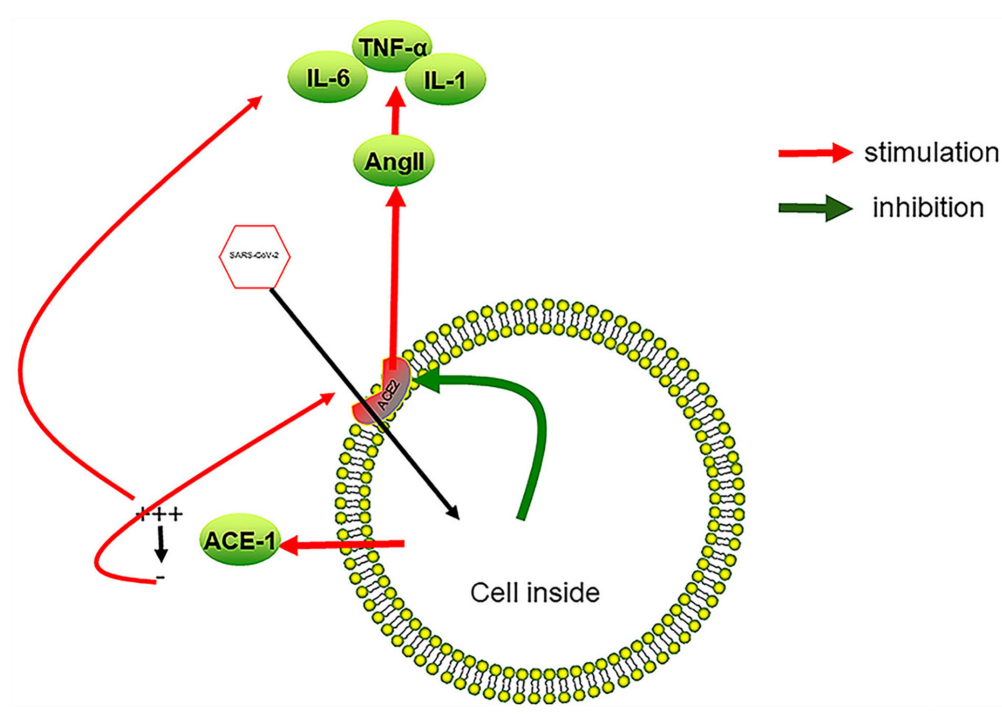

FIGURE 3 | SARS-CoV-2 infection causes inflammation of vascular endothelial cells. After SARS-CoV-2 enters endothelial cells from ACE2, it promotes the reduction of ACE2 on the cell surface, which in turn leads to an increase in Angll in the blood, a decrease in local anti-inflammatory ability, and an increase in the expression of cytokines such as TNF- $\alpha$, IL-6, and IL-1. Overexpression of inflammatory factors leads to the damage of vascular endothelial cells and the formation of a local procoagulant state. On the other hand, SARS-CoV-2 causes ACE1 to fall off the cell surface at the initial stage of infection, which promotes local plasma leakage and the expression of inflammatory factors. As the free ACE1 drops to a very low level, ACE2 is induced, which, in turn, promotes SARS-CoV-2 to enter endothelial cells. A vicious cycle between SARS-CoV-2 infection and overexpression of inflammatory factors forms. 
and factor 12 (FXII) in the coagulation pathway; and play other downstream roles in enhancing the procoagulant reaction of the endogenous coagulation pathway (104). The imbalance of gastrointestinal microbiota and the influence of gastrointestinal microbiota metabolites on the complications of intestinal thrombosis is also a point worth studying.

\section{THE GASTROINTESTINAL SYMPTOMS OF COVID-19 PATIENTS AND ITS INFLUENCE ON THE PROGNOSIS OF THE DISEASE}

A number of large-scale case studies reported the clinical characteristics of patients with COVID-19 infection. In addition to the most common symptoms of fever and cough, each case study report also had gastrointestinal symptoms (105112). Due to differences in institutions and regions, and the lack of a unified standard for judging gastrointestinal symptoms, the incidence of gastrointestinal symptoms in these studies is not the same. The most common of these was the case study of Zhang's team; $39.6 \%$ of patients had gastrointestinal symptoms. In studies that include more cases of severely ill patients, the incidence of gastrointestinal symptoms has increased significantly. The symptoms included nausea, diarrhea, loss of appetite, abdominal pain, hiccups, and vomiting (111). Some cases were even accompanied by gastrointestinal bleeding (113, 114), intussusception $(5,115,116)$, emphysema (117), and acute intestinal ischemia $(118,119)$. In some cases, severe gastrointestinal symptoms were the first manifestation, such as rectal perforation (120), acute pancreatitis (121), gastrointestinal bleeding (122), and colitis (123). This may be related to the underlying disease of the gastrointestinal tract (124). Gastrointestinal symptoms can be the first manifestation of COVID-19 infection. The underlying mechanism may be due to the expression of ACE2 in intestinal epithelial cells, making the digestive system a potential route of infection (125). Gastrointestinal symptoms have a certain familial clustering. A study from Bangladesh showed that if patients had gastrointestinal symptoms, their family members were at increased risk of infection and are more likely to develop gastrointestinal symptoms (126).

Diarrhea often indicated a severe type of inflammation, so it was more important for the prognosis of patients $(67,116,127)$. Xi's case-control study pointed out that patients with gastrointestinal symptoms had a significantly higher chance of developing critical cases than patients without gastrointestinal symptoms (128), and they were more likely to develop critical diseases such as ARDS, liver injury, and shock (129). In critically ill patients, the inflammation caused by viral infection was severe, the intestinal damage was aggravated, and the incidence of acute gastrointestinal injury was as high as $86.7 \%$ (130), and it often indicated a higher mortality rate (130-134). This suggested a vicious cycle between the intestinal damage caused by SARS$\mathrm{CoV}-2$ and the inflammatory response caused by it. In addition, almost half of the new coronavirus patients with gastrointestinal symptoms in a study developed after treatment, and were at increased risk of severe disease (135). Inappropriate treatment may also be a risk factor for inducing gastrointestinal symptoms. However, the research of Nobel, Yael R. showed that the appearance of gastrointestinal symptoms often indicated that the disease is "slow but not serious", and gastrointestinal diseases will not hinder the host's immune response to SARS-COV-2. The occurrence of gastrointestinal symptoms may be related to the faster reduction of viral load through the fecal route (136). Even among the many possible risk factors, the lack of gastrointestinal symptoms predicted reduced survival rates for all age groups (137). Patients with gastrointestinal symptoms when the test was positive had a significantly lower case fatality rate compared with those who were asymptomatic, but the course of the disease was longer $(136,138)$. Patients with only gastrointestinal symptoms had a milder illness and lower mortality than those with respiratory symptoms (139). This may be due to the low level of inflammation in the lamina propria cells of the gastrointestinal tract, the downregulation of inflammatory genes, and the reduction of major inflammatory proteins in the gastrointestinal tract, which weakened the inflammatory response caused by SARS-CoV-2 (140). Diarrhea was also an independent factor predicting lower mortality (141). On the other hand, some studies pointed out that the current results were not enough to prove that there was a significant correlation between the gastrointestinal symptoms of patients with the new coronavirus and the severity of the disease (142). The gastrointestinal symptoms of COVID-19 were common and had nothing to do with poor prognosis, the need for mechanical ventilation, and mortality $(143,144)$. To determine the relationship between gastrointestinal symptoms and disease prognosis, it was also necessary to exclude therapeutic effects, the indirect effects of cytokines, and the effects of drugs, as well as higher-level clinical research evidence (145). In this regard, the case-control study of Liu pointed out that compared with gastrointestinal symptoms, stool examination had a stronger correlation with patients' severe and critical illness, so it provided more valuable information (146). Viral load also played an important role in assessing the severity of SARSCoV-2 and other viral infections (51). Based on this, the most important thing to pay attention to is the early detection of potential infections, especially the isolated gastrointestinal tract. Patients with symptoms should take timely and effective preventive measures to prevent the hidden spread of the virus in the population.

\section{SUMMARY}

COVID-19 is the third coronavirus disease in this century. It has erupted globally since the end of 2019. The main symptoms of infection were fever, cough, and other lung symptoms. Some patients had gastrointestinal symptoms, such as diarrhea, abdominal pain, and vomiting. The main route of transmission is direct contact transmission, including droplet transmission and close contact transmission. Some patients had infectious SARS- 
CoV-2 in their feces, which suggested that SARS-CoV-2 could be transmitted through fecal-oral route. Gastrointestinal symptoms caused by COVID-19 occurred in patients with mild or severe infection, and their manifestations were diverse. Diarrhea and anorexia were the most common symptoms. Some serious diseases such as intestinal perforation and volvulus were also reported from time to time. It is difficult to draw a conclusion about the relationship between gastrointestinal symptoms and prognosis. The consensus is that the most important thing to note is to identify patients with gastrointestinal infections as the first manifestation. The direct causes of intestinal symptoms caused by SARS-CoV-2 were virus infection, cytokine release syndrome, or cytokine storm. Immune response disorder, intestinal flora disorder, vascular underwear cell damage, and thromboembolism were also the causes of severe gastrointestinal complications. Due to the existence of the gut-lung axis, the ecology of intestinal microbes is also of great significance to the development of pulmonary immunity and lung diseases. Therefore, we should also pay attention to the balance of the intestinal microorganisms, which will have a certain effect on the rehabilitation of patients and the reduction of normal human infections.

\section{REFERENCES}

1. Lu H, Stratton CW, Tang Y-W. Outbreak of Pneumonia of Unknown Etiology in Wuhan, China: The Mystery and the Miracle. J Med Virol (2020) 92:401-2. doi: 10.1002/jmv.25678

2. Gupta S, Parker J, Smits S, Underwood J, Dolwani S. Persistent Viral Shedding of SARS-CoV-2 in Faeces - a Rapid Review. Colorectal Dis (2020) 22:611-20. doi: 10.1111/codi.15138

3. van Doorn AS, Meijer B, Frampton CMA, Barclay ML, de Boer NKH. Systematic Review With Meta-Analysis: SARS-CoV-2 Stool Testing and the Potential for Faecal-Oral Transmission. Aliment Pharmacol Ther (2020) 52:1276-88. doi: 10.1111/apt.16036

4. Du W, Yu J, Liu X, Chen H, Lin L, Li Q. Persistence of SARS-CoV-2 Virus RNA in Feces: A Case Series of Children. J Infect Public Health (2020) 13:926-31. doi: 10.1016/j.jiph.2020.05.025

5. Lin L, Jiang X, Zhang Z, Huang S, Zhang Z, Fang Z, et al. Gastrointestinal Symptoms of 95 Cases With SARS-CoV-2 Infection. Gut (2020) 69:9971001. doi: 10.1136/gutjnl-2020-321013

6. Simmons G, Zmora P, Gierer S, Heurich A, Pöhlmann S. Proteolytic Activation of the SARS-Coronavirus Spike Protein: Cutting Enzymes at the Cutting Edge of Antiviral Research. Antiviral Res (2013) 100:605-14. doi: 10.1016/j.antiviral.2013.09.028

7. Kuba K, Imai Y, Rao S, Gao H, Guo F, Guan B, et al. A Crucial Role of Angiotensin Converting Enzyme 2 (ACE2) in SARS Coronavirus-Induced Lung Injury. Nat Med (2005) 11:875-9. doi: 10.1038/nm1267

8. Hamming I, Timens W, Bulthuis ML, Lely AT, Navis G, van Goor H. Tissue Distribution of ACE2 Protein, the Functional Receptor for SARS Coronavirus. A First Step in Understanding SARS Pathogenesis. J Pathol (2004) 203:631-7. doi: 10.1002/path.1570

9. Du M, Cai G, Chen F, Christiani DC, Zhang Z, Wang M. Multiomics Evaluation of Gastrointestinal and Other Clinical Characteristics of COVID-19. Gastroenterology (2020) 158:2298-2301.e2297. doi: 10.1053/ j.gastro.2020.03.045

10. Liang W, Feng Z, Rao S, Xiao C, Xue X, Lin Z, et al. Diarrhoea may be Underestimated: A Missing Link in 2019 Novel Coronavirus. Gut (2020) 69:1141-3. doi: 10.1136/gutjnl-2020-320832

11. Zhang J, Wang S, Xue Y. Fecal Specimen Diagnosis 2019 Novel Coronavirus-Infected Pneumonia. J Med Virol (2020) 92:680-2. doi: $10.1002 / j m v .25742$

\section{AUTHOR CONTRIBUTIONS}

HZ, BS, QD, ZC, QZ and HL are responsible for writing the manuscript, and $\mathrm{HZ}$ is responsible for the revision of the manuscript. HZ and BS contributed equally to this work. ZS and WY are responsible for the editing of the manuscript. All authors contributed to the article and approved the submitted version.

\section{FUNDING}

This study was supported by the National Natural Science Foundation of China (81972663 and 81560385), the Key Scientific Research Projects of Institutions of Higher Education in Henan Province (19A310024), the Medical Scientific and Technological Research Project of Henan Province (201702027), the Youth Innovation Fund Project of The First Affiliated Hospital of Zhengzhou University (YNQN2017035), the China Postdoctoral Science Foundation (2019T120648, 2017M610462), the National Natural Science Foundation of Henan Province (182300410342), and the Health Commission Technology Talents Overseas Training Project of Henan Province (2018140).

12. Xiao F, Tang M, Zheng X, Liu Y, Li X, Shan H. Evidence for Gastrointestinal Infection of SARS-CoV-2. Gastroenterology (2020) 158:1831-3.e1833. doi: 10.1053/j.gastro.2020.02.055

13. Hirose R, Nakaya T, Naito Y, Daidoji T, Watanabe Y, Yasuda H, et al. Mechanism of Human Influenza Virus RNA Persistence and Virion Survival in Feces: Mucus Protects Virions From Acid and Digestive Juices. J Infect Dis (2017) 216:105-9. doi: 10.1093/infdis/jix224

14. Chin AWH, Chu JTS, Perera MRA, Hui KPY, Yen HL, Chan MCW, et al Stability of SARS-CoV-2 in Different Environmental Conditions. Lancet Microbe (2020) 1:e10. doi: 10.1016/s2666-5247(20)30003-3

15. Kumar A, Faiq MA, Pareek V, Raza K, Narayan RK, Prasoon P, et al. Relevance of SARS-CoV-2 Related Factors ACE2 and TMPRSS2 Expressions in Gastrointestinal Tissue With Pathogenesis of Digestive Symptoms, DiabetesAssociated Mortality, and Disease Recurrence in COVID-19 Patients. Med Hypotheses (2020) 144:110271. doi: 10.1016/j.mehy.2020.110271

16. Leung WK, To KF, Chan PK, Chan HL, Wu AK, Lee N, et al. Enteric Involvement of Severe Acute Respiratory Syndrome-Associated Coronavirus Infection. Gastroenterology (2003) 125:1011-7. doi: 10.1016/s0016-5085(03) 01215-0

17. Jeong HW, Kim SM, Kim HS, Kim YI, Kim JH, Cho JY, et al. Viable SARSCoV-2 in Various Specimens From COVID-19 Patients. Clin Microbiol Infect Off Publ Eur Soc Clin Microbiol Infect Dis (2020) 26:1520-4. doi: 10.1016/j.cmi.2020.07.020

18. Hanna JS, Herrera-Almario GE, Pinilla-Roncancio M, Tulloch D, Valencia SA, Sabatino ME, et al. Use of the Six Core Surgical Indicators From the Lancet Commission on Global Surgery in Colombia: A Situational Analysis. Lancet Global Health (2020) 8:e699-710. doi: 10.1016/s2214-109x (20)30090-5

19. Lamers MM, Beumer J, van der Vaart J, Knoops K, Puschhof J, Breugem TI, et al. SARS-CoV-2 Productively Infects Human Gut Enterocytes. Science (2020) 369:50-4. doi: 10.1126/science.abc1669

20. Chu H, Chan JF, Wang Y, Yuen TT, Chai Y, Shuai H, et al. SARS-CoV-2 Induces a More Robust Innate Immune Response and Replicates Less Efficiently Than SARS-CoV in the Human Intestines: An Ex Vivo Study With Implications on Pathogenesis of COVID-19. Cell Mol Gastroenterol Hepatol (2021) 11:771-81. doi: 10.1016/j.jcmgh.2020.09.017

21. Hu F, Chen F, Ou Z, Fan Q, Tan X, Wang Y, et al. A Compromised Specific Humoral Immune Response Against the SARS-CoV-2 Receptor-Binding Domain is Related to Viral Persistence and Periodic Shedding in the 
Gastrointestinal Tract. Cell Mol Immunol (2020) 17:1119-25. doi: 10.1038/ s41423-020-00550-2

22. Li X-J, Zhang Z-W, Zong Z-Y. A Case of a Readmitted Patient Who Recovered From COVID-19 in Chengdu, China. Crit Care (2020) 24:152. doi: 10.1186/s13054-020-02877-8

23. Cuicchi D, Lazzarotto T, Poggioli G. Fecal-Oral Transmission of SARSCoV-2: Review of Laboratory-Confirmed Virus in Gastrointestinal System. Int J Colorectal Dis (2020) 36(3):437-44. doi: 10.1007/s00384-020-03785-7

24. Ling $\mathrm{Y}, \mathrm{Xu}$ SB, Lin YX, Tian D, Zhu ZQ, Dai FH, et al. Persistence and Clearance of Viral RNA in 2019 Novel Coronavirus Disease Rehabilitation Patients. Chin Med J (Engl) (2020) 133:1039-43. doi: 10.1097/CM9. 0000000000000774

25. Wang J, Chen C, Li Q, Cai P, Wang Z, Wang L. COVID-19 Confirmed Patients With Negative Antibodies Results. BMC Infect Dis (2020) 20:698. doi: 10.1186/s12879-020-05419-3

26. Osman AA, Al Daajani MM, Alsahafi AJ. Re-Positive Coronavirus Disease 2019 PCR Test: Could it be a Reinfection? New Microbes New Infect (2020) 37:100748. doi: 10.1016/j.nmni.2020.100748

27. Kumar A, Kumari C, Faiq MA, Pareek V, Narayan RK. SARS-CoV-2 Infectivity Vis-A-Vis Human Gut and Mesentery: Pathogenic Implications for COVID-19. Soc Sci Electron Publ. doi: 10.13140/RG.2.2.34820.96644

28. Lambert DW, Clarke NE, Turner AJ. Not Just Angiotensinases: New Roles for the Angiotensin-Converting Enzymes. Cell Mol Life Sci (2010) 67:89-98. doi: 10.1007/s00018-009-0152-x

29. Tipnis SR, Hooper NM, Hyde R, Karran E, Christie G, Turner AJ. A Human Homolog of Angiotensin-Converting Enzyme. Cloning and Functional Expression as a Captopril-Insensitive Carboxypeptidase. J Biol Chem (2000) 275:33238-43. doi: 10.1074/jbc.M002615200

30. Crackower MA, Sarao R, Oudit GY, Yagil C, Kozieradzki I, Scanga SE, et al. Angiotensin-Converting Enzyme 2 is an Essential Regulator of Heart Function. Nature (2002) 417:822-8. doi: 10.1038/nature00786

31. Elmarakby AA, Bhatia K, Crislip R, Sullivan JC. Hemodynamic Responses to Acute Angiotensin II Infusion are Exacerbated in Male Versus Female Spontaneously Hypertensive Rats. Physiol Rep (2016) 4:e12677. doi: $10.14814 /$ phy2.12677

32. Vukelic S, Griendling KK, Angiotensin II. From Vasoconstrictor to Growth Factor: A Paradigm Shift. Circ Res (2014) 114:754-7. doi: 10.1161/ CIRCRESAHA.114.303045

33. Donoghue M, Hsieh F, Baronas E, Godbout K, Gosselin M, Stagliano N, et al. A Novel Angiotensin-Converting Enzyme-Related Carboxypeptidase (ACE2) Converts Angiotensin I to Angiotensin 1-9. Circ Res (2000) 87: E1-9. doi: 10.1161/01.RES.87.5.e1

34. Santos RAS, Simoes e Silva AC, Maric C, Silva DM, Machado RP, de Buhr I, et al. Angiotensin-(1-7) is an Endogenous Ligand for the G Protein-Coupled Receptor Mas. Proc Natl Acad Sci USA (2003) 100:8258-63. doi: 10.1073/ pnas. 1432869100

35. Meng Y, Yu CH, Li W, Li T, Luo W, Huang S, et al. Angiotensin-Converting Enzyme 2/Angiotensin-(1-7)/Mas Axis Protects Against Lung Fibrosis by Inhibiting the MAPK/NF-kb Pathway. Am J Respir Cell Mol Biol (2014) 50:723-36. doi: 10.1165/rcmb.2012-0451OC

36. Lan J, Ge J, Yu J, Shan S, Zhou H, Fan S, et al. Structure of the SARS-CoV-2 Spike Receptor-Binding Domain Bound to the ACE2 Receptor. Nature (2020) 581:215-20. doi: 10.1038/s41586-020-2180-5

37. Yan R, Zhang Y, Li Y, Xia L, Guo Y, Zhou Q. Structural Basis for the Recognition of SARS-CoV-2 by Full-Length Human ACE2. Sci (New York NY) (2020) 367:1444-8. doi: 10.1126/science.abb2762

38. Lu R, Zhao X, Li J, Niu P, Yang B, Wu H, et al. Genomic Characterisation and Epidemiology of 2019 Novel Coronavirus: Implications for Virus Origins and Receptor Binding. Lancet (London England) (2020) 395:56574. doi: 10.1016/s0140-6736(20)30251-8

39. Zhou P, Yang XL, Wang XG, Hu B, Zhang L, Zhang W, et al. A Pneumonia Outbreak Associated With a New Coronavirus of Probable Bat Origin. Nature (2020) 579:270-3. doi: 10.1038/s41586-020-2012-7

40. Xiuyuan O, Yan L, Xiaobo L, Pei L, Dan M, Lili R, et al. Characterization of Spike Glycoprotein of SARS-CoV-2 on Virus Entry and its Immune CrossReactivity With SARS-CoV. Nat Commun (2020) 11:1620. doi: 10.1038/ s41467-020-15562-9
41. Li W, Moore MJ, Vasilieva N, Sui J, Wong SK, Berne MA, et al. AngiotensinConverting Enzyme 2 is a Functional Receptor for the SARS Coronavirus. Nature (2003) 426:450-4. doi: 10.1038/nature02145

42. Rowaiye AB, Onuh OA, Oli AN, Okpalefe OA, Oni S, Nwankwo EJ. The Pandemic COVID-19: A Tale of Viremia, Cellular Oxidation and Immune Dysfunction. Pan Afr Med J (2020) 36:188. doi: 10.11604/pamj.2020. 36.188.23476

43. Sanchez-Gonzalez MA, Moskowitz D, Issuree PD, Yatzkan G, Rizvi SAA, Day KA. A Pathophysiological Perspective on COVID-19's Lethal Complication: From Viremia to Hypersensitivity Pneumonitis-Like Immune Dysregulation. Infect Chemother (2020) 52:335-44. doi: 10.3947/ ic.2020.52.3.335

44. Tan C, Li S, Liang Y, Chen M, Liu J. SARS-CoV-2 Viremia may Predict Rapid Deterioration of COVID-19 Patients. Braz J Infect Dis Off Publ Braz Soc Infect Dis (2020) 24:565-9. doi: 10.1016/j.bjid.2020.08.010

45. Järhult JD, Hultström M, Bergqvist A, Frithiof R, Lipcsey M. The Impact of Viremia on Organ Failure, Biomarkers and Mortality in a Swedish Cohort of Critically Ill COVID-19 Patients. Sci Rep (2021) 11:7163. doi: 10.1038/ s41598-021-86500-y

46. Ebrahimi N, Aslani S, Babaie F, Hemmatzadeh M, Hosseinzadeh R, Joneidi Z, et al. Recent Findings on the Coronavirus Disease 2019 (COVID-19); Immunopathogenesis and Immunotherapeutics. Int Immunopharmacol (2020) 89:107082. doi: 10.1016/j.intimp.2020.107082

47. Katze MG, He Y, Gale MJr. Viruses and Interferon: A Fight for Supremacy. Nat Rev Immunol (2002) 2:675-87. doi: 10.1038/nri888

48. Bernet J, Mullick J, Singh AK, Sahu A. Viral Mimicry of the Complement System. J Biosci (2003) 28:249-64. doi: 10.1007/bf02970145

49. Schulz KS, Mossman KL. Viral Evasion Strategies in Type I IFN Signaling A Summary of Recent Developments. Front Immunol (2016) 7:498. doi: 10.3389/fimmu.2016.00498

50. Chen H, Zou TH, Xuan B, Yan Y, Yan T, Shen C, et al. Single Cell Transcriptome Revealed SARS-CoV-2 Entry Genes Enriched in Colon Tissues and Associated With Coronavirus Infection and Cytokine Production. Signal Transduct Target Ther (2020) 5:121. doi: 10.1038/s41392-020-00237-0

51. Dahiya DS, Kichloo A, Albosta M, Pagad S, Wani F. Gastrointestinal Implications in COVID-19. J Investig Med (2020) 68(8):1397-401. doi: 10.1136/jim-2020-001559

52. Garg S, Garg M, Prabhakar N, Malhotra P, Agarwal R. Unraveling the Mystery of Covid-19 Cytokine Storm: From Skin to Organ Systems. Dermatol Ther (2020) 33:e13859. doi: 10.1111/dth.13859

53. Chu H, Chan JF, Wang Y, Yuen TT, Chai Y, Shuai H, et al. SARS-CoV-2 Induces a More Robust Innate Immune Response and Replicates Less Efficiently Than SARS-CoV in the Human Intestines: An Ex Vivo Study With Implications on Pathogenesis of COVID-19. Cell Mol Gastroenterol Hepatol (2020) 11(3):771-81. doi: 10.1016/j.jcmgh.2020.09.017

54. Pedersen SF, Ho Y-C. SARS-CoV-2: A Storm is Raging. J Clin Invest (2020) 130:2202-5. doi: 10.1172/JCI137647

55. Schurink B, Roos E, Radonic T, Barbe E, Bouman CSC, de Boer HH, et al. Viral Presence and Immunopathology in Patients With Lethal COVID-19: A Prospective Autopsy Cohort Study. Lancet Microbe (2020) 1:e290-9. doi: 10.1016/S2666-5247(20)30144-0

56. Tay MZ, Poh CM, Rénia L, MacAry PA, Ng LFP. The Trinity of COVID-19: Immunity, Inflammation and Intervention. Nat Rev Immunol (2020) 20:363-74. doi: 10.1038/s41577-020-0311-8

57. Rosen HR, O'Connell C, Nadim MK, DeClerck B, Sheibani S, DePasquale E, et al. Extrapulmonary Manifestations of Severe Acute Respiratory Syndrome Coronavirus-2 (SARS-CoV-2) Infection. J Med Virol (2020) 93(5):2645-53. doi: $10.1002 / j m v .26595$

58. Qi F, Qian S, Zhang S, Zhang Z. Single Cell RNA Sequencing of 13 Human Tissues Identify Cell Types and Receptors of Human Coronaviruses. Biochem Biophys Res Commun (2020) 526:135-40. doi: 10.1016/ j.bbrc.2020.03.044

59. Merad M, Martin JC. Pathological Inflammation in Patients With COVID19: A Key Role for Monocytes and Macrophages. Nat Rev Immunol (2020) 20:355-62. doi: 10.1038/s41577-020-0331-4

60. Lax SF, Skok K, Zechner P, Kessler HH, Kaufmann N, Koelblinger C, et al. Pulmonary Arterial Thrombosis in COVID-19 With Fatal Outcome : Results 
From a Prospective, Single-Center, Clinicopathologic Case Series. Ann Intern Med (2020) 173:350-61. doi: 10.7326/M20-2566

61. Conti P, Caraffa A, Gallenga CE, Ross R, Kritas SK, Frydas I, et al. Coronavirus-19 (SARS-CoV-2) Induces Acute Severe Lung Inflammation via IL-1 Causing Cytokine Storm in COVID-19: A Promising Inhibitory Strategy. J Biol Regul Homeost Agents (2020) 34:1971-5. doi: 10.23812/20-1-E

62. Tisoncik JR, Korth MJ, Simmons CP, Farrar J, Martin TR, Katze MG. Into the Eye of the Cytokine Storm. Microbiol Mol Biol Rev (2012) 76:16-32. doi: 10.1128/MMBR.05015-11

63. Tanaka T, Narazaki M, Kishimoto T. IL-6 in Inflammation, Immunity, and Disease. Cold Spring Harb Perspect Biol (2014) 6:a016295. doi: 10.1101/ cshperspect.a016295

64. Kimura A, Kishimoto T. IL-6: Regulator of Treg/Th17 Balance. Eur J Immunol (2010) 40:1830-5. doi: 10.1002/eji.201040391

65. Eguchi S, Kawai T, Scalia R, Rizzo V. Understanding Angiotensin II Type 1 Receptor Signaling in Vascular Pathophysiology. Hypertension (2018) 71:804-10. doi: 10.1161/HYPERTENSIONAHA.118.10266

66. Murakami M, Kamimura D, Hirano T. Pleiotropy and Specificity: Insights From the Interleukin 6 Family of Cytokines. Immunity (2019) 50:812-31. doi: 10.1016/j.immuni.2019.03.027

67. Zhang L, Han C, Zhang S, Duan C, Shang H, Bai T, et al. Diarrhea and Altered Inflammatory Cytokine Pattern in Severe Coronavirus Disease 2019: Impact on Disease Course and in-Hospital Mortality. J Gastroenterol Hepatol (2020) 36(2):421-9. doi: 10.1111/jgh.15166

68. Wang D, Hu B, Hu C, Zhu F, Liu X, Zhang J, et al. Clinical Characteristics of 138 Hospitalized Patients With 2019 Novel Coronavirus-Infected Pneumonia in Wuhan, China. Jama (2020) 323(11):1061-9. doi: 10.1001/ jama.2020.1585

69. Ding Y, He L, Zhang Q, Huang Z, Che X, Hou J, et al. Organ Distribution of Severe Acute Respiratory Syndrome (SARS) Associated Coronavirus (SARS-CoV) in SARS Patients: Implications for Pathogenesis and Virus Transmission Pathways. J Pathol (2004) 203:622-30. doi: 10.1002/ path. 1560

70. Wan Y, Shang J, Graham R, Baric RS, Li F. Receptor Recognition by the Novel Coronavirus From Wuhan: An Analysis Based on Decade-Long Structural Studies of SARS Coronavirus. J Virol (2020) 94(7):e00127-20. doi: 10.1128/jvi.00127-20

71. Hashimoto T, Perlot T, Rehman A, Trichereau J, Ishiguro H, Paolino M, et al. ACE2 Links Amino Acid Malnutrition to Microbial Ecology and Intestinal Inflammation. Nature (2012) 487:477-81. doi: 10.1038/nature11228

72. Singer D, Camargo SM, Ramadan T, Schäfer M, Mariotta L, Herzog B, et al. Defective Intestinal Amino Acid Absorption in Ace2 Null Mice. Am J Physiol Gastrointest Liver Physiol (2012) 303:G686-95. doi: 10.1152/ajpgi. 00140.2012

73. Kowalczuk S, Bröer A, Tietze N, Vanslambrouck JM, Rasko JE, Bröer S. A Protein Complex in the Brush-Border Membrane Explains a Hartnup Disorder Allele. FASEB J (2008) 22:2880-7. doi: 10.1096/fj.08-107300

74. Camargo SM, Singer D, Makrides V, Huggel K, Pos KM, Wagner CA. Tissue-Specific Amino Acid Transporter Partners ACE2 and Collectrin Differentially Interact With Hartnup Mutations. Gastroenterology (2009) 136:872-82. doi: 10.1053/j.gastro.2008.10.055

75. Broer A, Juelich T, Vanslambrouck JM, Tietze N, Solomon PS, Holst J, et al. Impaired Nutrient Signaling and Body Weight Control in a $\mathrm{Na}+$ Neutral Amino Acid Cotransporter (Slc6a19)-Deficient Mouse. J Biol Chem (2011) 286:26638-51. doi: 10.1074/jbc.M111.241323

76. Nikolaus S, Schulte B, Al-Massad N, Thieme F, Schulte DM, Bethge J, et al. Increased Tryptophan Metabolism Is Associated With Activity of Inflammatory Bowel Diseases. Gastroenterology (2017) 153:1504-16.e1502. doi: 10.1053/j.gastro.2017.08.028

77. Jando J, Camargo SMR, Herzog B, Verrey F. Expression and Regulation of the Neutral Amino Acid Transporter B0AT1 in Rat Small Intestine. PloS One (2017) 12:e0184845. doi: 10.1371/journal.pone.0184845

78. Lv L, Jiang H, Chen Y, Gu S, Xia J, Zhang H, et al. The Faecal Metabolome in COVID-19 Patients is Altered and Associated With Clinical Features and Gut Microbes. Analytica Chim Acta (2021) 1152:338267. doi: 10.1016/ j.aca.2021.338267

79. Catanzaro M, Fagiani F, Racchi M, Corsini E, Govoni S, Lanni C. Immune Response in COVID-19: Addressing a Pharmacological Challenge by
Targeting Pathways Triggered by SARS-CoV-2. Signal Transduct Target Ther (2020) 5:84. doi: 10.1038/s41392-020-0191-1

80. McIlroy JR, Mullish BH, Goldenberg SD, Ianiro G, Marchesi JR. Intestinal Microbiome Transfer, a Novel Therapeutic Strategy for COVID-19 Induced Hyperinflammation?: In Reply to, 'COVID-19: Immunology and Treatment Options', Felsenstein, Herbert McNamara Et al. 2020'. Clin Immunol (2020) 218:108542. doi: 10.1016/j.clim.2020.108542

81. Sharma S, Kumar R, Shalimar. Management of Gastrointestinal Bleeding in Coronavirus Disease: Exploring the Options. Am J Gastroenterol (2020) 116 (4):843-4. doi: 10.14309/ajg.0000000000000979

82. Rodriguez-Nakamura RM, Gonzalez-Calatayud M, Martinez Martinez AR. Acute Mesenteric Thrombosis in Two Patients With COVID-19. Two Cases Report and Literature Review. Int J Surg Case Rep (2020) 76:409-14. doi: 10.1016/j.ijscr.2020.10.040

83. Bhayana R, Som A, Li MD, Carey DE, Anderson MA, Blake MA, et al. Abdominal Imaging Findings in COVID-19: Preliminary Observations. Radiology (2020) 297:E207-15. doi: 10.1148/radiol.2020201908

84. Giuffrè M, Di Bella S, Sambataro G, Zerbato V, Cavallaro M, Occhipinti AA, et al. COVID-19-Induced Thrombosis in Patients Without Gastrointestinal Symptoms and Elevated Fecal Calprotectin: Hypothesis Regarding Mechanism of Intestinal Damage Associated With COVID-19. Trop Med Infect Dis (2020) 5:147. doi: 10.3390/tropicalmed5030147

85. Chan KH, Lim SL, Damati A, Maruboyina SP, Bondili L, Abu Hanoud A, et al. Coronavirus Disease 2019 (COVID-19) and Ischemic Colitis: An UnderRecognized Complication. Am J Emerg Med (2020) 38(12):2758.e1-4. doi: 10.1016/j.ajem.2020.05.072

86. Farina D, Rondi P, Botturi E, Renzulli M, Borghesi A, Guelfi D, et al. Gastrointestinal: Bowel Ischemia in a Suspected Coronavirus Disease (COVID-19) Patient. J Gastroenterol Hepatol (2020) 36(1):41. doi: 10.1111/jgh.15094

87. Mestres G, Puigmacià R, Blanco C, Yugueros X, Esturrica M, Riambau V. Risk of Peripheral Arterial Thrombosis in COVID-19. J Vasc Surg (2020) 72:756-7. doi: 10.1016/j.jvs.2020.04.477

88. Llitjos J-F, Leclerc M, Chochois C, Monsallier JM, Ramakers M, Auvray M, et al. High Incidence of Venous Thromboembolic Events in Anticoagulated Severe COVID-19 Patients. J Thromb Haemost (2020) 18:1743-6. doi: $10.1111 /$ jth.14869

89. Li Y, Cao Y, Zeng Z, Liang M, Xue Y, Xi C, et al. Angiotensin-Converting Enzyme 2/Angiotensin-(1-7)/Mas Axis Prevents LipopolysaccharideInduced Apoptosis of Pulmonary Microvascular Endothelial Cells by Inhibiting JNK/NF-Kb Pathways. Sci Rep (2015) 5:8209. doi: 10.1038/ srep08209

90. Aimes RT, Zijlstra A, Hooper JD, Ogbourne SM, Sit ML, Fuchs S, et al. Endothelial Cell Serine Proteases Expressed During Vascular Morphogenesis and Angiogenesis. Thromb Haemost (2003) 89:561-72. doi: $10.1055 / \mathrm{s}-0037-1613388$

91. Jose RJ, Manuel A. COVID-19 Cytokine Storm: The Interplay Between Inflammation and Coagulation. Lancet Respir Med (2020) 8:e46-7. doi: 10.1016/S2213-2600(20)30216-2

92. Radeva MY, Waschke J. Mind the Gap: Mechanisms Regulating the Endothelial Barrier. Acta Physiol (Oxf) (2018) 222. doi: 10.1111/apha.12860

93. Souza LL, Costa-Neto CM. Angiotensin-(1-7) Decreases LPS-Induced Inflammatory Response in Macrophages. J Cell Physiol (2012) 227:211722. doi: $10.1002 / j$ cp. 22940

94. Kasal DA, De Lorenzo A, Tibiriçá E. COVID-19 and Microvascular Disease: Pathophysiology of SARS-CoV-2 Infection With Focus on the ReninAngiotensin System. Heart Lung Circ (2020) 29:1596-602. doi: 10.1016/ j.hlc. 2020.08 .010

95. Ranucci M, Ballotta A, Di Dedda U, Baryshnikova E, Dei Poli M, Resta M, et al The Procoagulant Pattern of Patients With COVID-19 Acute Respiratory Distress Syndrome. I Thromb Haemost (2020) 18:1747-51. doi: 10.1111/ jth. 14854

96. Pamukçu B. Inflammation and Thrombosis in Patients With COVID-19: A Prothrombotic and Inflammatory Disease Caused by SARS Coronavirus-2. Anatol J Cardiol (2020) 24:224-34. doi: 10.14744/AnatolJCardiol.2020. 56727

97. Liu Z, Xiao X, Wei X, Li J, Yang J, Tan H, et al. Composition and Divergence of Coronavirus Spike Proteins and Host ACE2 Receptors Predict Potential 
Intermediate Hosts of SARS-CoV-2. J Med Virol (2020) 92:595-601. doi: $10.1002 / j m v .25726$

98. Leisman DE, Deutschman CS, Legrand M. Facing COVID-19 in the ICU: Vascular Dysfunction, Thrombosis, and Dysregulated Inflammation. Intensive Care Med (2020) 46:1105-8. doi: 10.1007/s00134-020-06059-6

99. Guzik TJ, Mohiddin SA, Dimarco A, Patel V, Savvatis K, Marelli-Berg FM, et al. COVID-19 and the Cardiovascular System: Implications for Risk Assessment, Diagnosis, and Treatment Options. Cardiovasc Res (2020) 116:1666-87. doi: 10.1093/cvr/cvaa106

100. Connors JM, Levy JH. COVID-19 and its Implications for Thrombosis and Anticoagulation. Blood (2020) 135:2033-40. doi: 10.1182/blood.2020006000

101. Levi M, Thachil J, Iba T, Levy JH. Coagulation Abnormalities and Thrombosis in Patients With COVID-19. Lancet Haematol (2020) 7:e43840. doi: 10.1016/S2352-3026(20)30145-9

102. Zhang L, Yan X, Fan Q, Liu H, Liu X, Liu Z, et al. D-Dimer Levels on Admission to Predict in-Hospital Mortality in Patients With Covid-19. J Thromb Haemost (2020) 18:1324-9. doi: 10.1111/jth.14859

103. Mehta P, McAuley DF, Brown M, Sanchez E, Tattersall RS, Manson JJ, et al. COVID-19: Consider Cytokine Storm Syndromes and Immunosuppression. Lancet (2020) 395:1033-4. doi: 10.1016/S0140-6736(20)30628-0

104. Smith SA, Mutch NJ, Baskar D, Rohloff P, Docampo R, Morrissey JH. Polyphosphate Modulates Blood Coagulation and Fibrinolysis. Proc Natl Acad Sci USA (2006) 103:903-8. doi: 10.1073/pnas.0507195103

105. Cappell MS. Moderately Severe Diarrhea and Impaired Renal Function With COVID-19 Infection. Am J Gastroenterol (2020) 115:947-8. doi: 10.14309/ ajg.0000000000000681

106. Shi H, Han X, Jiang N, Cao Y, Alwalid O, Gu J, et al. Radiological Findings From 81 Patients With COVID-19 Pneumonia in Wuhan, China: A Descriptive Study. Lancet Infect Dis (2020) 20:425-34. doi: 10.1016/S14733099(20)30086-4

107. Sun S-H, Chen Q, Gu HJ, Yang G, Wang YX, Huang XY, et al. A Mouse Model of SARS-CoV-2 Infection and Pathogenesis. Cell Host Microbe (2020) 28:124-33.e4. doi: 10.1016/j.chom.2020.05.020

108. Huang C, Wang Y, Li X, Ren L, Zhao J, Hu Y, et al. Clinical Features of Patients Infected With 2019 Novel Coronavirus in Wuhan, China. Lancet (2020) 395:497-506. doi: 10.1016/S0140-6736(20)30183-5

109. Zost SJ, Gilchuk P, Case JB, Binshtein E, Chen RE, Nkolola JP, et al. Potently Neutralizing and Protective Human Antibodies Against SARS-CoV-2. Nature (2020) 584:443-9. doi: 10.1038/s41586-020-2548-6

110. Chen A, Agarwal A, Ravindran N, To C, Zhang T, Thuluvath PJ. Are Gastrointestinal Symptoms Specific for Coronavirus 2019 Infection? A Prospective Case-Control Study From the United States. Gastroenterology (2020) 159:1161-3.e2. doi: 10.1053/j.gastro.2020.05.036

111. Wong SH, Lui RN, Sung JJ. Covid-19 and the Digestive System. J Gastroenterol Hepatol (2020) 35:744-8. doi: 10.1111/jgh.15047

112. Jiang R-D, Liu MQ, Chen Y, Shan C, Zhou YW, Shen XR, et al. Pathogenesis of SARS-CoV-2 in Transgenic Mice Expressing Human Angiotensin-Converting Enzyme 2. Cell (2020) 182:50-8.e8. doi: 10.1016/j.cell.2020.05.027

113. Karki S, Rawal SB, Malla S, Rayamajhi J, Thapa BB. A Case Report on Spontaneous Hemoperitoneum in COVID-19 Patient. Int J Surg Case Rep (2020) 75:211-3. doi: 10.1016/j.ijscr.2020.09.078

114. Li X, Huang S, Lu J, Lai R, Zhang Z, Lin X, et al. Upper Gastrointestinal Bleeding Caused by SARS-CoV-2 Infection. Am J Gastroenterol (2020) 115:1541-2. doi: 10.14309/ajg.0000000000000757

115. Moazzam Z, Salim A, Ashraf A, Jehan F, Arshad M. Intussusception in an Infant as a Manifestation of COVID-19. J Pediatr Surg Case Rep (2020) 59:101533. doi: 10.1016/j.epsc.2020.101533

116. Kumar A, Arora A, Sharma P, Anikhindi SA, Bansal N, Singla V, et al. Gastrointestinal and Hepatic Manifestations of Corona Virus Disease-19 and Their Relationship to Severe Clinical Course: A Systematic Review and MetaAnalysis. Indian J Gastroenterol (2020) 39:268-84. doi: 10.1007/s12664-02001058-3

117. Meini S, Zini C, Passaleva MT, Frullini A, Fusco F, Carpi R, et al. Pneumatosis Intestinalis in COVID-19. BMJ Open Gastroenterol (2020) 7: e000434. doi: 10.1136/bmjgast-2020-000434

118. Chiu CY, Sarwal A, Mon AM, Tan YE, Shah V. Gastrointestinal: COVID-19 Related Ischemic Bowel Disease. J Gastroenterol Hepatol (2020) 36(4):850. doi: $10.1111 /$ jgh. 15254
119. Cheung S, Quiwa JC, Pillai A, Onwu C, Tharayil ZJ, Gupta R. Superior Mesenteric Artery Thrombosis and Acute Intestinal Ischemia as a Consequence of COVID-19 Infection. Am J Case Rep (2020) 21:e925753. doi: 10.12659/AJCR.925753

120. Giuffrè M, Bozzato AM, Di Bella S, Occhipinti AA, Martingano P, Cavallaro MFM, et al. Spontaneous Rectal Perforation in a Patient With SARS-CoV-2 Infection. J Pers Med (2020) 10:157. doi: 10.3390/jpm10040157

121. Purayil N, Sirajudeen J, Va N, Mathew J. COVID-19 Presenting as Acute Abdominal Pain: A Case Report. Cureus (2020) 12:e9659. doi: 10.7759/ cureus. 9659

122. Chen T, Yang Q, Duan H. A Severe Coronavirus Disease 2019 Patient With High-Risk Predisposing Factors Died From Massive Gastrointestinal Bleeding: A Case Report. BMC Gastroenterol (2020) 20:318. doi: 10.1186/ s12876-020-01458-x

123. Khader M, Al Bishawi A, Kambal A, Abdelmajid A. SARS-CoV-2 Infection Presenting as Colitis With Chest and Abdomen CT Findings. Radiol Case Rep (2020) 15:2427-32. doi: 10.1016/j.radcr.2020.09.035

124. Grover S, Redd WD, Zhou JC, Nije C, Wong D, Hathorn KE, et al. High Prevalence of Gastrointestinal Manifestations of COVID-19 Infection in Hospitalized Patients With Cancer. J Clin Gastroenterol (2020) 55(1):84-7. doi: 10.1097/MCG.0000000000001462

125. Wu C-Y, Yu XP, Ma AHY, Wang LP, Yang NB, Li GX, et al. Coronavirus Disease 19 With Gastrointestinal Symptoms as Initial Manifestations: A Case Report. J Int Med Res (2020) 48:300060520952256. doi: 10.1177/ 0300060520952256

126. Khalil MM, Gain G, Mahbub-Uz-Zaman K, Karim ME, Sarker KD, Akter D, et al. Gastrointestinal Manifestations Among COVID-19 Patients in Bangladesh: A Cross Sectional Study. Mymensingh Med J (2020) 29:956-63.

127. Schulz C, Mayerle J, Stubbe HC, Sirtl S, Lerch MM, Malfertheiner P. [COVID-19 From a Gastroenterological Perspective]. Dtsch Med Wochenschr (2020) 145:1033-8. doi: 10.1055/a-1167-5825

128. Jin X, Lian JS, Hu JH, Gao J, Zheng L, Zhang YM, et al. Epidemiological, Clinical and Virological Characteristics of 74 Cases of Coronavirus-Infected Disease 2019 (COVID-19) With Gastrointestinal Symptoms. Gut (2020) 69:1002-9. doi: 10.1136/gutjnl-2020-320926

129. Adukia SA, Ruhatiya RS, Maheshwarappa HM, Manjunath RB, Jain GN. Extrapulmonary Features of COVID-19: A Concise Review. Indian J Crit Care Med (2020) 24:575-80. doi: 10.5005/jp-journals-10071-23476

130. Sun J-K, Liu Y, Zou L, Zhang WH, Li JJ, Wang Y, et al. Acute Gastrointestinal Injury in Critically Ill Patients With COVID-19 in Wuhan, China. World J Gastroenterol (2020) 26:6087-97. doi: 10.3748/wjg.v26.i39.6087

131. Li H, Zhang D, Wang Y, Zhao S. Association Between Acute Gastrointestinal Injury Grading System and Disease Severity and Prognosis in Critically Ill Patients: A Multicenter, Prospective, Observational Study in China. J Crit Care (2016) 36:24-8. doi: 10.1016/j.jcrc.2016.05.001

132. Hu B, Sun R, Wu A, Ni Y, Liu J, Guo F, et al. Severity of Acute Gastrointestinal Injury Grade is a Predictor of All-Cause Mortality in Critically Ill Patients: A Multicenter, Prospective, Observational Study. Crit Care (2017) 21:188. doi: 10.1186/s13054-017-1780-4

133. Zhang D, Li Y, Ding L, Fu Y, Dong X, Li H. Prevalence and Outcome of Acute Gastrointestinal Injury in Critically Ill Patients: A Systematic Review and Meta-Analysis. Med (Baltimore) (2018) 97:e12970. doi: 10.1097/ MD.0000000000012970

134. Reintam Blaser A, Malbrain ML, Starkopf J, Fruhwald S, Jakob SM, De Waele J, et al. Gastrointestinal Function in Intensive Care Patients: Terminology, Definitions and Management. Recommendations of the ESICM Working Group on Abdominal Problems. Intensive Care Med (2012) 38:384-94. doi: 10.1007/s00134-011-2459-y

135. Ianiro G, Porcari S, Settanni CR, Bibbò S, Ponziani FR, Zileri Dal Verme L, et al. Letter: Prevalence and Patterns of Gastrointestinal Symptoms in a Large Western Cohort of Patients With COVID-19. Aliment Pharmacol Ther (2020) 52:902-3. doi: 10.1111/apt.15946

136. Nobel YR, Phipps M, Zucker J, Lebwohl B, Wang TC, Sobieszczyk ME, et al. Gastrointestinal Symptoms and Coronavirus Disease 2019: A Case-Control Study From the United States. Gastroenterology (2020) 159:373-5.e372. doi: 10.1053/j.gastro.2020.04.017

137. Renelus BD, Khoury N, Chandrasekaran K, Bekele E, Briggs WM, Jamorabo DS. Hospitalized Coronavirus Disease-2019 (COVID-19) Patients With 
Gastrointestinal Symptoms Have Improved Survival to Discharge. Dig Liver Dis (2020) 52(12):1403-6. doi: 10.1016/j.dld.2020.08.043

138. Laszkowska M, Faye AS, Kim J, Truong H, Silver ER, Ingram M, et al. Disease Course and Outcomes of COVID-19 Among Hospitalized Patients With Gastrointestinal Manifestations. Clin Gastroenterol Hepatol (2020) 19 (7):1402-9.e1. doi: 10.1016/j.cgh.2020.09.037

139. Sulaiman T, Algharawi AA, Idrees M, Alzaidy RH, Faris K, Cullingford G, et al. The Prevalence of Gastrointestinal Symptoms Among Patients With COVID-19 and the Effect on the Severity of the Disease. JGH Open (2020) 4 (6):1162-6. doi: 10.1002/jgh3.12415

140. Livanos AE, Jha D, Cossarini F, Gonzalez-Reiche AS, Tokuyama M, Aydillo T, et al. Gastrointestinal Involvement Attenuates COVID-19 Severity and Mortality. medRxiv (2020) 2020.09.07.20187666. doi: 10.1101/2020.09.07. 20187666

141. Schettino M, Pellegrini L, Picascia D, Saibeni S, Bezzio C, Bini F, et al. Clinical Characteristics of COVID-19 Patients With Gastrointestinal Symptoms in Northern Italy: A Single-Center Cohort Study. Am J Gastroenterol (2020) 116(2):306-10. doi: 10.14309/ajg.0000000000000965

142. Liu J, Cui M, Yang T, Yao P. Correlation Between Gastrointestinal Symptoms and Disease Severity in Patients With COVID-19: A Systematic Review and Meta-Analysis. BMJ Open Gastroenterol (2020) 7:e000437. doi: 10.1136/bmjgast-2020-000437

143. Cao C, Chen M, He L, Xie J, Chen X. Clinical Features and Outcomes of COVID-19 Patients With Gastrointestinal Symptoms. Crit Care (2020) 24:340. doi: 10.1186/s13054-020-03034-x

144. Ramachandran P, Onukogu I, Ghanta S, Gajendran M, Perisetti A, Goyal $\mathrm{H}$, et al. Gastrointestinal Symptoms and Outcomes in Hospitalized
Coronavirus Disease 2019 Patients. Dig Dis (2020) 38:373-9. doi: $10.1159 / 000509774$

145. Parigi TL, Vespa E, Pugliese N, Danese S. COVID-19 and Gastrointestinal Symptoms: The Dust has Not Settled Yet. Expert Rev Gastroenterol Hepatol (2020) 14:877-8. doi: 10.1080/17474124.2020.1801415

146. Liu Y, Xiang L, Deng K. Focusing on Gastrointestinal Symptoms in COVID19 Is Far From Enough. Gastroenterology (2021) 160:1429-30.e1422. doi: 10.1053/j.gastro.2020.05.043

Conflict of Interest: The authors declare that the research was conducted in the absence of any commercial or financial relationships that could be construed as a potential conflict of interest.

Publisher's Note: All claims expressed in this article are solely those of the authors and do not necessarily represent those of their affiliated organizations, or those of the publisher, the editors and the reviewers. Any product that may be evaluated in this article, or claim that may be made by its manufacturer, is not guaranteed or endorsed by the publisher.

Copyright $\odot 2021$ Zhang, Shao, Dang, Chen, Zhou, Luo, Yuan and Sun. This is an open-access article distributed under the terms of the Creative Commons Attribution License (CC BY). The use, distribution or reproduction in other forums is permitted, provided the original author(s) and the copyright owner(s) are credited and that the original publication in this journal is cited, in accordance with accepted academic practice. No use, distribution or reproduction is permitted which does not comply with these terms. 